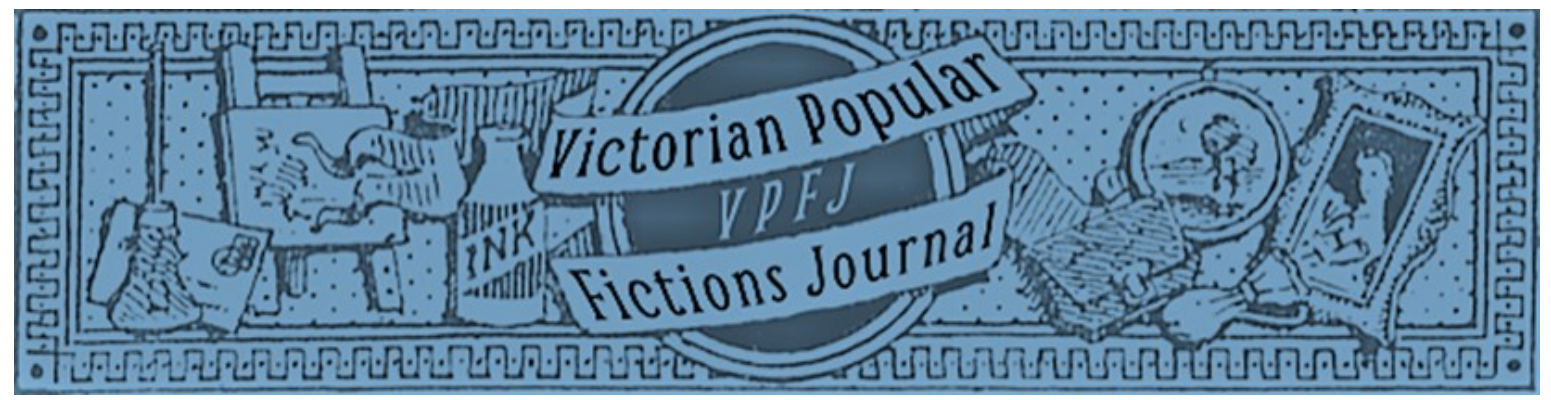

\title{
Melodramatic Mayhew: \\ J.B. Johnstone's How We Live in the World of London
}

\section{Taryn Hakala}

\begin{abstract}
The British stage of the1850s produced a flurry of dramas influenced by Henry Mayhew's work on urban poverty, many of which were written for the "minor" theatres of London's East End and the south side of the Thames. Often dismissed as literary "hacks," the writers for these theatres and their works have been largely undervalued and understudied. This article shines a spotlight on one such writer, John Beer Johnstone, whose How We Live in the World of London; Or, London Labour and the London Poor premiered at the Surrey Theatre on 24 March 1856. Taking a positive view of literary "piracy," I argue that Johnstone's play cleverly re-imagines Mayhew's social journalism and subverts prevalent stereotypes of the urban poor for the Surrey's mixed audiences.
\end{abstract}

\section{Keywords}

John Beer Johnstone; Henry Mayhew; adaptation; piracy; theatre; melodrama; class

Date of Acceptance: 8 December 2021

Date of Publication: 17 December 2021

Double Blind Peer Reviewed

\section{Recommended Citation:}

Hakala, Taryn. 2021. "Melodramatic Mayhew: J.B. Johnstone's How We Live in the World of London." Victorian Popular Fictions, 3.2: 116-133. ISSN: 2632-4253 (online) DOI: https://doi.org/10.46911/ AXJA8957

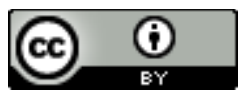

This work is licensed under a Creative Commons Attribution 4.0 International License. 


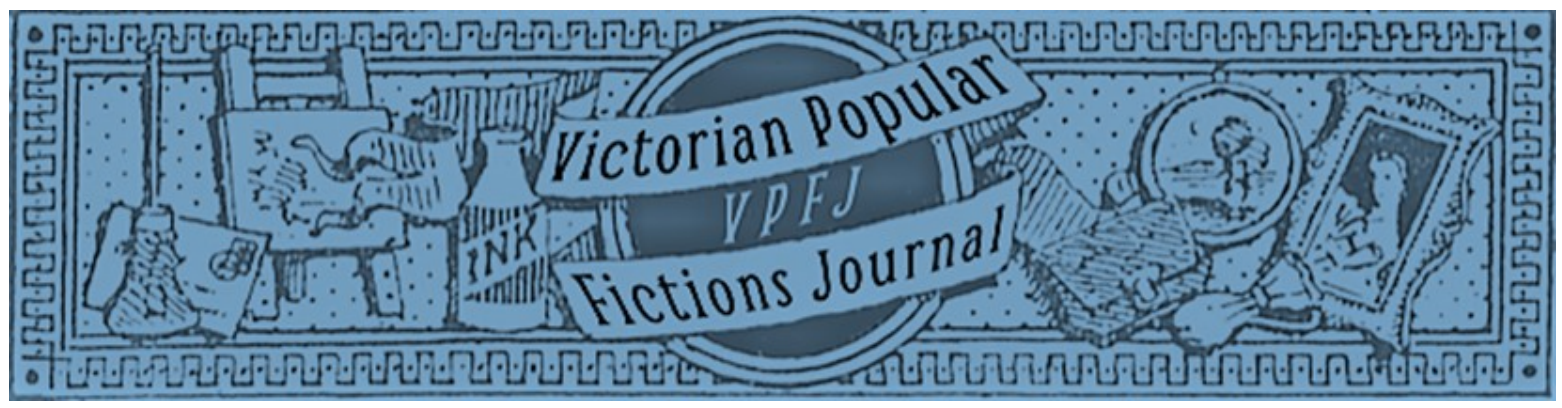

\title{
Melodramatic Mayhew: J.B. Johnstone's How We Live in the World of London
}

\author{
Taryn Hakala
}

\section{Introduction}

On 6 April 1856, Lloyd's Weekly Newspaper reviewed a new drama at the Surrey by John Beer Johnstone (1803-1891) titled How We Live in the World of London and "suggested by Mr. Henry Mayhew, who, in his 'London Labour and the London Poor,' and 'Great World of London,' undertakes to tell nine-tenths of the great metropolitans how the other five-sixths live" ("Public Amusements" 1856: 8). The reviewer informs us that the "majority of the characters we have already met in the streets. No later than yesterday did we see Russia Bob, a canine connoiseur [sic] in Regent-street," while "Captain George, a street patterer, [...] is taken bodily from the Tottenham-court-road, and transplanted to the Obelisk" (8). This cataloguing of characters continues until the reviewer remembers that the play has a newly invented plot and a fictional aristocratic villain:

the whole tribe of banjo-players, costermongers, goundsell-sellers, the wanderers and outcasts generally, unite in some peculiar manner to frustrate the felonious designs of a Great British baronet! Yes. We had quite forgotten, in the excitement of meeting old friends, that there is a plot to the drama.

Regarding the plot, the reviewer finds it "so horrible and improbable, and, at the same time, so old as to be really comic" but later praises the "perfection of the street characters and the scenery", concluding that "Altogether this is a new style of drama which is very attractive, and deserving of great success" (8).

I begin with this review from Lloyd's Weekly Newspaper because it speaks to questions of genre, adaptation, originality, and representation that this article will explore. The street-folk, whom audience members know from both the pages of London Labour and the London Poor and the streets of London themselves, mingle with the stock characters of melodrama, while the play itself is both "old as to be really comic" and "a new style of drama." The final lines of the review are especially telling: "But whilst on the subject, let us hope that Mr. Mayhew, in his next edition, will not again shirk the question of the atrocious baronet. 
Belgravia is aghast at the disclosure" (8). Certainly, some facetiousness can be detected in this remark, but the suggestion that Mayhew should borrow a character from Johnstone's melodrama to be considered in the next issue of his nonfiction prose work further speaks to questions of originality and the slipperiness of generic categories.

Deborah Vlock has discussed how Mayhew violates what we might consider the "integrity of genre" in London Labour, and how that violation suggests nineteenth-century readers "were accustomed to reading plays in their novels, novels in their non-fiction prose, and so on, without necessarily recognizing the generic slippage as anything of the sort" (1998: 118). Furthermore, Vlock reveals the ways in which Mayhew relied on theatrical conventions in his representations of London street-folk, how London Labour's "'realizations' of life on the street, to borrow Martin Meisel's terminology, partake generously of dramatic and literary stereotypes" (118). Mayhew, then, had already borrowed from the stage in his representation of London street-folk before dramatists borrowed from his work for the stage. Mayhew's participation in the theatre and his own dramatisation of London Labour is a subject I return to later in the essay.

As well-recognised as the mutual influence of drama and prose fiction now is, it is the dramatists who are still often dismissed as "hacks" and "pirates" and their work derided as simply derivative. Recent scholarship in nineteenth-century theatre, however, has argued for the importance of the study of theatrical adaptations. In her introduction to a special issue of Nineteenth Century Theatre and Film on adaptation, for example, Janice Norwood argues that the plays produced by these "hack" dramatists are deserving of scholarly examination not only because they "formed a substantial proportion of the Victorian dramatic repertoire" but also because, "Much of the vitality of nineteenth-century drama can be attributed to the continual inventive re-imagining of plots, characters and motifs from fiction, poetry, the visual arts and music" (2015: 3, 5). Similarly, in her recent study of literary piracy, Monica Cohen reveals a pattern in which pirates, the sea-faring kind, are represented as "charismatic storytellers and dramatic entertainers" even by authors whose work had been pirated. She detects in pirate fiction a consistent admiration of "forms of collective ownership" and a mobilising of "a set of references whereby a history of free creative sharing between page and stage emerges" (2017: 2). This article continues this positive view of literary piracy, considering John Beer Johnstone not as a "hack" but as an inventive re-imaginer of a wide variety of texts. I will focus on Johnstone's re-imaging of Mayhew's London Labour and will show that the play does not simply cater to working-class audiences but rather speaks to mixed audiences and attempts to re-educate that audience about the lives of London's street-folk by using and reworking the conventions of melodrama in ways that convey positive representations of the urban poor.

\section{Surrey-Siders and London Labour}

The Surrey Theatre was located near the Obelisk on Blackfriars Road in Southwark on the south side of the Thames. Its rival the Victoria Theatre was located in nearby Lambeth, only a tenminute walk away. Although the Surrey and the Victoria were within walking distance from each other, we cannot assume that the theatres catered to or drew the same audiences. As Jim Davis and Victor Emeljanow have shown, though they surely shared the same audience at times, the Surrey drew not only a mixed local audience but also theatregoers from other areas of London. By contrast, the Victoria catered to a mostly local, popular audience $(2001: 39,25)$. 
After the passing of the Theatre Regulation Act in 1843, the Victoria made very little change to their repertoire, whereas the management of the Surrey, including Richard Shepherd who took over in 1848, "developed a policy that mingled melodrama, farce, Shakespeare, the legitimate drama, and the opera [...] The intention was evidently to offer a diversity of attractions, presumably to draw and/or cater to a diversity of playgoers" (2001: 25).

We cannot, therefore, suggest, as Andrew Maunder can in the case of John Courtney's stage adaptation of Elizabeth Gaskell's Mary Barton for the Victoria in February 1851, that Johnstone "re-visioned" Mayhew's London Labour for working-class audiences. Maunder points out that audiences of Courtney's Mary Barton; or, A Tale of Manchester Life would have encountered Gaskell's story "as part of a mixed bill of theatrical entertainments and against the backdrop of local preoccupations" and that the production "exported Gaskell to a new and different audience who had not necessarily read the two-volume novel" (2011:2). While the same can be said for Johnstone's How We Live in terms of the context of a mixed bill, we should be careful not to assume that "local preoccupations" were the same for all members of the audience, or that they had not encountered London Labour in other contexts. As we have established, the Surrey's audience included theatregoers from all classes and from both the local area and other neighbourhoods of London. Furthermore, as Bertrand Taithe points out, "Mayhew wrote a number of different texts called London Labour, at different periods, and aimed at different readerhips" (4). The project began in 1849 when Mayhew was hired by the Morning Chronicle as their London correspondent, and then continued as a series of weekly pamphlets published between December 1850 and February 1852. The four-volume edition readers are now most familiar with was not published until 1862, and very little of its fourth volume was written by Mayhew. "This "polymorphic" project, then, "was read according to how it was presented: as part of an expensive newspaper; as a cheap, penny periodical sold alongside 'penny dreadfuls,' and as an expensive, four-volume book" (Taithe 1996: 5).

In addition, Londoners may have encountered London Labour through one of its many paratexts. In her study of the "extensive media ecology of London Labour," including the supplemental Answers to Correspondents series, Jenna Herdman has argued that "the poor were producers of their own history, who responded to Mayhew as critical readers, protesters, and self-advocates. Instead of upholding the power binary between a middle-class journalist and a desperate member of an impoverished class, street-sellers used their relationships with Mayhew and their access to print media to assert their own culture" (2021: 384, 386). Johnstone also participated in the extensive media ecology of London Labour and his play responds to Mayhew as a "critical reader," upending the power binary established by Mayhew in his work on street-sellers and asserting alternate representations of them. Mary Shannon comments that the "adapter becomes a privileged type of reader, who can share (or inflict) their reading upon others" (2015: 141). We might argue that Johnstone shares (or inflicts) his reading of London Labour and its paratexts on the Surrey's mixed audience. How We Live re- imagines London Labour for the members of the audience, some of whom were street-sellers themselves, and others of whom were not, but could empathise with their struggles. But the play also does important work to re-educate members of the audience who read London Labour as fact, challenging Mayhew's representation of street-folk.

\footnotetext{
${ }^{1}$ For the publication history of London Labour, see Humpherys (1984: 81-159); Taithe (1996: 13-21); and Schroeder.
} 


\section{John Beer Johnstone}

John Beer Johnstone wrote over two hundred plays during his nearly four-decade-long career. ${ }^{2}$ Johnstone wrote everything from melodramas and pantomimes to comediettas, farces, and burlesques. Most of these plays were written for the "minor" theatres on the south side of the Thames, such as the Surrey and the Victoria, and in the East End, such as the Britannia, the Effingham, the Pavilion, and the Standard, but he also wrote for theatres on the fringe of the West End, including the Marylebone. Like many playwrights of the era, Johnstone wrote several adaptations of popular fiction or imitations of other plays. Before bringing his re-imagining of Mayhew's London Labour to the stage, Johnstone dramatised Charles Wilkins Webber's Gothic Western Jack Long; Or, the Shot in the Eye for the Victoria in 1847, George Cruikshank's series of eight plates The Drunkard's Children for the Royal Pavilion in 1848, John Frederick Smith's serialised novels Minnigrey and Woman and Her Master for the Standard in 1852 and 1854, respectively, as well as the popular song "Ben Bolt" for the Surrey in 1854, and Charles Dickens's story "The Seven Poor Travellers" for the Surrey in 1855. He would later take on Dickens's "The Holly Tree Inn" in 1856 and Oliver Twist in 1868, both for the Surrey, as well as James Malcolm Rymer's "The Will o' the Wisp" and Frederick and James Greenwood's Under a Cloud, both for the Effingham in 1859. He also adapted two novels by Mary Elizabeth Braddon, who incidentally played Clara in How We Live, Aurora Floyd for the Marylebone in 1863 and Eleanor's Victory for the Victoria in 1864. Johnstone also wrote imitations of other plays, including a burlesque of Dion Boucicault's The Colleen Bawn, called The Cooleen Drawn, for the Surrey in 1861, and Avarice for the Surrey in 1857, a reworking of John Palgrave Simpson's Daddy Hardacre, itself an adaptation of Honoré de Balzac's novel Eugénie Grandet.

Early in Richard Shepherd and William Creswick's management of the Surrey, Johnstone was also the theatre's regular prompter and Pantaloon in their pantomimes (Knight 1997: 244). Indeed, Johnstone was active onstage and off, acting in nearly every London theatre by $1891{ }^{3}$ As John Russell Stephens points out, it was not uncommon for actors to move into the playwrighting profession and to continue acting once they did so (1992: 7). For some playwrights, including Johnstone, continuing to act was partly a financial decision. As an actor, Johnstone often earned less than two pounds per week. As an author he "fared still worse," as he explains:

Transpontine authors were in my time as plentiful as blackberries, and almost as cheap; and I never, as one of them, got upon an average of a $£ 5$ note, until Mr. Barrett gave me about six times that amount for the piece I wrote for him.

("The Oldest Actor on the Stage" 1883: 8)

Johnstone goes on to say that he sometimes received considerably less than that and cites an incident when he was offered only fifteen shillings for an extravaganza and a farce:

\footnotetext{
${ }^{2}$ According to the Pall Mall Gazette, Johnstone "was the author of over 150 dramas and pantomimes" ("An Old London Actor" 1891: 6). By his own account, Johnstone had written over 200 plays by 1883. Other sources state that he wrote "about 200 dramas" ("Theatrical and Musical Intelligence" 1886: 3).

3 According to the Pall Mall Gazette, Johnstone "had acted in almost every London theatre" (“An Old London Actor" 1891: 6).

${ }^{4}$ While some West End playwrights saw a marked increase in their earnings from the 1860s onwards, those who wrote for transpontine and East End theatres, "where there was a rapid turnover of plays to satisfy frequent changes of programme," did not (Stephens 1992: 52).
} 
For instance, one thriving manager, Mr Osbaldiston, in his liberal treatment of me, I will mention. I went to him after a phantom breakfast, and with every prospect of a phantom dinner, with an extravaganza and a farce. He turned over the manuscript, he looked dubious, whilst I feared, and in the end offered fifteen shillings for the two. I need not tell you I took it, and such was my necessity that I should have done the same if it had been fifteen pence.

He then continues his narrative to explain why he did not try to sell his plays in the West End, where he might have received more compensation:

If I had ventured to do so at that time -such was the prejudice against transpontine writers - that I verily believe the manager would have given me in charge of the police, and taken me before a magistrate on the charge of 'obtaining money under false pretences.'

Johnstone may have been being somewhat hyperbolic and attempting humour here in suggesting he risked arrest, but the message that transpontine playwrights could be exploited and were often impecunious still comes through.

Johnstone narrated these events on 12 March 1883, when a large gathering of actors and actor-managers, including Wilson Barrett and J.L. Toole, gathered at the Princess's theatre in London to present him with a testimonial on his eightieth birthday. The testimonial bore nearly 200 signatures, including those of Henry Irving, Ellen Terry, Mary Anne Keeley, the Kendals, Dion Boucicault, Arthur Wing Pinero, and Henry Arthur Jones. The celebration was held after a performance of The Silver King, by Henry Arthur Jones (1851-1929), at the Princess's Theatre in the West End, in which Johnstone played the character of Gaffer Pottle. During the celebration, Johnstone was presented with "a purse of gold amounting to sixty pounds" ("The Oldest Actor on the Stage" 1883: 8). This gift of money was meant to remunerate Johnstone for his many contributions to the British stage, for his sixty years as an actor, and even more so for his forty years as a prolific playwright who received shamefully inadequate compensation. Johnstone remarked, "I need not tell you, for a man in my position, how serviceable the money gift will be" (8). The context of Johnstone's remarks makes them all the more poignant. He had just performed in Jones's The Silver King, for which Jones earned more than $£ 18,000$ during his lifetime (Booth 1965: 48). ${ }^{5}$ Johnstone deserved more than the pittance he received for most of his plays. Johnstone also deserves more scholarly attention for his contributions to nineteenth-century theatre.

\section{Johnstone's How We Live in the World of London}

The 1850s saw a flurry of dramas influenced by Mayhew's work on urban poverty. These included James Elphistone's London Labour and the London Poor, or Want and Vice, which premiered at the Royal Pavilion on 18 March 1854, but also played at the Victoria in July under the title The Fiend of the Fleet; or London Labour and London Poor, ${ }^{6}$ C.H. Hazlewood's The Wild Tribes, which premiered at the City of London Theater on 31 May 1856, and Johnstone's dramatisation of Augustus Mayhew's novel, Paved with Gold: The Romance and Reality of the London Streets, which premiered at the Victoria on 20 September 1858. According to Tony Williams, it is Johnstone's How We Live in the World

\footnotetext{
${ }^{5}$ Led by Dion Boucicault, in the 1860s, dramatists began asking for a percentage of the profits from their plays. Prior to the 1860 s, authors received one payment only for their work. See Booth (1965: 47-8).

${ }^{6}$ See "Royal Victoria Theatre" (1854: 6).
} 
of London "that the most direct attempt to present Mayhew's approach on the stage is made" (2000: 136). In addition to using many of the locales featured in London Labour, Johnstone's dramatisation also includes more characters based on the London street-folk than the other plays influenced by Mayhew, and "the street characters speak for themselves, at times in harrowing detail" (2000: 141). As I will show, while Johnstone's How We Live in the World of London does echo London Labour in several ways, it also challenges and subverts it in several others.

In March 1856, Mayhew, with David Bogue, began publishing a new monthly periodical The Great World of London. Newspaper advertisements announced the scope of the new periodical, which promised to explore all scenes of London Life: "Its Hard Life, its Easy Life: its Drawing-room and Garret Life; its Industrious, Idle, Business, and Pleasure Life; its Highways, and Byeways, and Slyways; its 'Pluralities of Worlds"” ("Henry Mayhew's New Periodical on London and Londoners" 1856: 1). In addition, the first number of The Great World of London, published on 1 March 1856, announced that the publication of London Labour would recommence: "[Mr Mayhew] has much pleasure in stating that The London Street Folk will be forthwith completed" (Mayhew 1856). When Johnstone's How We Live in the World of London premiered on 24 March, then, there was a renewed buzz about Mayhew's work and "characters." The play enjoyed a successful run through 9 May and was revived for several weeks in late September. Unless you attended the staged reading of the play at the North American Victorian Studies Association conference in Banff National Park in 2017, you were likely unfamiliar with the plot. ${ }^{7}$ The play begins with Arthur Townbred, a London lawyer, escorting his friend Charles Roseleaf, a country attorney, through Covent Garden Market, where they encounter Joe Bunt, a costermonger, whose "services in an affair of secrecy and some little danger" the lawyers enlist (I. i.). As we soon learn, Charles and his fiancée, Clara, have been separated by her cruel uncle, Jasper Steelhard, the "atrocious baronet" of the Lloyd's review cited above. Sir Jasper's plan is to keep Clara captive in a private madhouse until she renounces Charles's love and signs a paper giving Sir Jasper control of her fortune and the right to choose her husband. Clara, of course, refuses to sign the paper and Sir Jasper leaves her in tears in the asylum. Thanks to the help of several London street-folk, including Joe Bunt the coster, Jerry Joyous the street boy, Captain George the street-patterer, and Araxa the Hindoo tract-seller, Clara is saved and reunited with Charles. Furthermore, Araxa's death-bed confession reveals that Jerry is actually the son of Sir Jasper and Lady Mary, who abandoned her husband and child when seduced by another man. Jerry is briefly reunited with his parents during the final scene in which Sir Jasper dies in a fire while attempting to burn documents that would implicate him a series of illegal activities. With the aid of Joe Bunt and Captain George, Jerry and Lady Mary escape the flames. The play ends with a spectacular street scene featuring the ruins of a burning house. Fire engines and the play's characters surround the dead form of Sir Jasper centre stage in the final tableau.

As you likely discerned from the plot summary, How We Live is a melodrama and follows many of that genre's traditions, such as the romantic hero and heroine being separated by a villainous aristocrat, the innocent orphan being threatened by the villain but is later revealed to be an heir to a fortune, the comic man aiding the hero in saving the heroine, and the villain meeting his demise at the end of the play. As Rohan McWilliam notes, nineteenth-century

\footnotetext{
${ }^{7}$ The Nineteenth-Century Theatre Caucus performed a staged reading of Johnstone's How We Live in the World of London at the North American Victorian Studies Association (NAVSA) conference in Banff, Alberta, Canada, November 16-18, 2017.
} 
English melodramas varied but were also predictable, which was part of their appeal. They shared a discourse that "included the acknowledgement of class, inequality, hierarchy, and power relations" (McWilliam 2018: 164). Melodramas were not necessarily politically radical, however. As McWilliam has shown, "the form was never the sole preserve of one social class, but a form of negotiation between different groups. [...] Melodrama reminded diverse audiences of the values that they shared" (166). One way Johnstone's How We Live accomplishes this is with its cross-class collection of heroes. For example, two middle-class lawyers team up with street-sellers to save Clara, and it is the street-sellers Joe Bunt and Captain George who save Jerry and Lady Mary from the flames that claim the villain's life. Moreover, Captain George, who was played by Richard Shepherd, represents not only street patterers but also soldiers. He is a former Captain of "the Buffs," the Royal East Kent Regiment, an infantry regiment, who has fallen on hard times. The Surrey audience would have included soldiers who could potentially see themselves in Captain George, as well as those who were familiar with the Buffs' action in the Crimean War from September 1855 newspaper reports. The character of Captain George provided audience members with a way to connect not only through patriotism, like the Jack Tars of nautical melodrama, but also across categories of class and rank. As a former member of the aristocracy who is now a street-seller of needles, Captain George represents both the good aristocrat and the respectable poor of melodrama.

One of the ways Johnstone's play differs from most nineteenth-century melodramas is how inheritance is handled. Yes, Jerry discovers that he is not a poor orphan after all. However, more emphasis is put on Jerry being taken home by the country attorney, Charles Roseleaf, to "make a young Lawyer of him" than on his claiming his inheritance; the latter is neither staged nor mentioned (III. ii.). The inheritance plot that receives more attention in the play is that of Joe Bunt, who inherits a fortune from his grandfather, "Newcastle Bill the Coaley." What Joe does with his fortune is also important. He explains that "to a select few that I really looks upon as my friends, I means to keep open House and a loan of a pound whenever they wants it" (III. ii.). This scene serves as a sequel to an earlier one in which Joe rebukes the porter of the Whitechapel Workhouse when he refuses to admit a woman and her sick child. When the porter asks Joe if he has an order to enter with the dying boy, Joe responds, "Order! I bear the common order that all should obey - humanity" (II. i.). With his "open House" Joe provides the care for London's poor that British society, with its workhouses and poorhouses, fails to. "If that isn't a proper way of making use of the wealth the coaley left me," Joe exclaims, "I don't know what is" (III. ii.). Throughout this scene, it is revealed that Joe has already made good on his promise; he has helped two of the play's street folk who in desperation had turned to dishonest means to earn their bread: Dick Alley and Banjo Bill. Joe, then, takes on the role of the benevolent paternalist of melodrama, one that was usually filled by a squire, landlord, or factory owner. In these ways, Joe's inheritance plot upends some of the traditional tropes of melodrama.

With How We Live, Johnstone also borrows aspects of urban plays, made popular by stage adaptations of Pierce Egan's Life in London, especially Moncrieff's Tom and Jerry; or, Life in London (1828). For example, Arthur Townbred, the London lawyer, and Charles Roseleaf, the country attorney, would have been familiar to audiences as "Tom and Jerry" types. Johnstone's play differs from the typical urban plays in important ways, however. As Heidi Holder points out, "the lessons Arthur teaches George [sic] have to do not with safely having a good time, but with assisting one's fellow creatures. Egan's dandies are now humanitarians" (2002: 39). Furthermore, it is not an upper-class "Bob Logic" type that acts as 
Arthur and Charles's guide, but rather a costermonger, Joe Bunt. Holder cites references to Joe's "nobility" in the play and notes "the reversal of the comedy of class inversion seen in Egan and [Charles] Mathews," in which characters make "ridiculous attempt[s] to ape 'noble' manners" (2002: 39).

I would add that Johnstone cleverly plays with verbal echoes of the opening scene of Moncrieff's play, in which Bob Logic explains the meaning of the word "blunt" to Tom and Jerry:

LOGIC: It's the blunt that does it - blunt makes the man, Jerry.

JERRY: Blunt! I'm at fault again.

TOM: Explain, Bob -

LOBIC: Blunt, my dear boy, is - in short what is it not? It's everything now o' days - to be able to flash the screens - sport the rhino - show the needful - post the pony - nap the rent stump the pewter - tip the brads - and down with the dust, is to be once good, great, handsome, accomplished, and everything that's desirable - money, money, is your universal God, - only get into Tip Street, Jerry.

In the opening scene of How We Live, Joe Bunt explains the meaning of the word "bunt" to Arthur and Charles:

JOE: [...] I remember when I made my first bunt -

CHARLES: Bunt! What do you mean by Bunt?

JOE: Lor bless me how ignorant, vell now, this is it - suppose a Boy's sent out with half a Bulls worth of goods and the cove says work these and bring me two and a tanner for the lot, all he gets over that is his own and is a fair bunt - that's the vay I got my first shallow and arrived ultimately at the dignity of a Donkey-cart.

Not only do the words "blunt" and "bunt" rhyme but also the structure of the dialogue is copied, with Jerry and Charles showing confusion and Bob and Joe defining the terms for them. Audiences would have recognised these parallels, not only because of enduring popularity of Moncrieff's play but also because it had appeared only a few months before at two East End theatres, the Britannia and the Garrick. Johnstone cleverly transforms the dialogue in two ways, however. First, he juxtaposes the original context of the conversation, Tom and Bob outfitting Jerry in the clothes of a "swell," with the realities of poverty for young street-sellers: "I was rising 13 before I knew what a shoe or stocking meant," explains Joe (I. i.). Mayhew reports several times in Volume 1 of London Labour the young street-sellers' lack of shoes and stockings. One of the most poignant examples is a quotation from an old seller of water-cresses:

Ah! it would make your heart ache if you was to go to Farringdon-market early, this cold weather, and see the poor little things there without shoes and stockings, and their feet quite blue with the cold - oh, that they are, and many on 'em don't know how to set one foot before the t'other, poor things. You would say they wanted something give to 'em.

(1851: 149)

Johnstone weaves together the language and imagery of both Moncrieff's urban play and Mayhew's urban journalism, making Joe Bunt an informant and an educator of those in the audience who do not understand, or need to be reminded of, the sufferings of the poor. 
The second way Johnstone transforms this scene is in the contrasting way the characters define slang terms. As Vlock has discussed, Bob Logic's speech, like that of the street patterers in London Labour, is "dissipated" and marked by "excessive wordiness and lapses in logic" (1998: 122). Joe's speech, on the other hand, though marked with phonological variation (/v/-/w/ inversion) and peppered with coster slang, is clear and logical. Admittedly, Joe could have simply said that "bunts" are "profits," but where is the fun in that? This is a play, after all, and Joe is one of its comic men. We would lose some of what Tony Williams calls the "stage impact and amusement" of this scene (2000: 146). Moreover, we would lose an interesting part of the definition; as Mayhew explains, costers often depute boys to sell their "goods for a certain sum, all over that amount being the boys' profit or 'bunts"” (1851: 33).

Tony Williams suggests that Johnstone avoids using "extreme examples of coster backslang [...] though Mayhew explores them in detail, presumably because Johnstone has to keep an awareness of the balance between realistic colour and avoiding confusion of his audience" (2000: 147). This may also be one of the reasons Johnstone renders Joe's speech more intelligible than Bob Logic's. Whatever the reasons, however, representing Joe's speech as lucid and logical and lacking in backslang, also constructs the coster as an intelligent and trustworthy character. When we contrast Joe's speech with Mayhew's rendition of coster speech in his July 1857 performance tour, Curious Conversazione, this becomes all the more evident. In these performances, Mayhew tried his hand at embodying the informants whose stories he narrated in his previous lecture tours. According to contemporary reviews, Mayhew would first give a short preamble "in his proper person," explaining what was to come. He then disappeared into a "tent" and reappeared in the costume of whichever informant he was to "personate," each character getting a quarter of an hour of stage time ("Mr. Henry Mayhew's Curious Conversazione" 1857: 6). Embodying each character in turn, Mayhew more closely resembled Charles Mathews in one of his monopolylogues than a journalist giving a lecture. ${ }^{8}$ The souvenir script, A Few Odd Characters Out of the London Streets, as Represented in Mr. Henry Mayhew's Curious Conversazione, includes character monologues of the London Costermonger, the Jew Clothes-Man, the Flying Stationer, the Professional Beggar, the Water-Cress Seller, and the Punch and Judy Man. In the souvenir script, Mayhew's London Costermonger not only uses extreme examples of backslang but also explains slang weights and measures:

But ve costers has got another kind o' slang besides a slang language, and that's [whispering] slang veights and measures. [...] Many of our coves used to have their veights beat out flat till they looked as big as muffins. But the people at last tumbled to that racket, so some of the costers has took to cork veights. Ah, you may open your mince-pies, my toolips! but I says cork veights, and means cork veights too.

[Looks round cautiously, and then takes a "dummy" weight from his pocket.]

Ye see [in a whisper] the veights is made holler, and is filled up hinside vith a big bung. Folks $d o$ tell a story, that vonce-te, ven the veights of a vet-fish cove down by the docks vos seized and chuckt into the river, they axully - vot d'ye think? - vy they axully floated down the stream.

(1857: 7-8)

\footnotetext{
${ }^{8}$ That Mayhew would embark on such a theatrical endeavour is not surprising when we remember that he both wrote for and appeared on the stage. For example, he wrote two farces, The Wandering Minstrel (1834) and But However - (1838), and acted in an 1845 production of Every Man in His Humour with Charles Dickens, Douglas Jerrold, and Mark Lemon.
} 
Mayhew also explains slang weights and measures in London Labour, but he makes no mention of cork or "dummy" weights, and there he gives voice to the costers to defend themselves. He quotes a "general dealer" who expresses the anger some costers felt toward their representation in Mayhew's letters to the Morning Chronicle and asserts that

There's plenty of costers wouldn't use slangs at all, if people would give a fair price; but you see the boys will try it on for their bunts, and how is a man to sell fine cherries at $4 d$. a pound that cost him $3 \frac{1}{2} d$., when there's a kid alongside of him a selling his 'tol' at $2 d$. a pound, and singing it out as bold as brass? So the men slangs it, and cries ' $2 d$. a pound,' and gives half-pound, as the boy does; which brings it to the same thing. We doesn't 'dulterate our goods like the tradesmen - that is, the regular hands doesn't. It wouldn't be easy, as you say, to 'dulterate cabbages or oysters; but we deals fair to all that's fair to us, - and that's more than many a tradesman does, for all their juries.

(1851:32)

The plain facts of the matter are spelled out here for the reader: most costers are honest but must make a living, and if their competition is using slangs how else are they to compete? The emphasis in this passage on fairness, and the insistence that the costers are even fairer than some other tradesman, drives the point home. The absence of this kind of discourse in Mayhew's comic performances make them more critical of the street-sellers than his series of articles, and some considered the performances a betrayal of his informants' trust. ${ }^{9}$

This was not the first time Mayhew came under fire for his portrayal of his informants, however. On 18 May 1851, G. W. M. Reynolds's periodical Reynolds's Newspaper began publishing reports of meetings of the Street Traders' Protection Association who came together to refute the statements put forth my Mayhew in London Labour. ${ }^{10} \mathrm{Mr}$. Taylor, the chairman, said that "Mr. Mayhew had tried to injure a class of society that never injured him; he had endeavoured to show that the street-sellers were devoid of honesty, decency, and of every virtue" ("London Labour and London Poor" 1851: 14). Mr. Palmer, a costermonger, said to "loud cheers" that

Mr. Mayhew got all his information from paid agents, men who would tell anything for money; and although that gentleman had endeavoured to rob the costers of their only capital, a good character, he (Mr. Palmer) could speak from experience and declare them to be a $[$ sic $]$ honest, hard-working, set of men.

(1851: 14)

With these declarations in mind, Arthur's lines describing costers in the opening scene of How We Live take on new resonance:

CHARLES: It's a wonderful mart!

ARTHUR: I should think it was when in the simple article of street dealing you'll find every market morning an average of 4000 costermongers.

CHARLES: Costermongers!

ARTHUR: An ancient calling, as old as the hills and at the present moment numbering 50,000 persons, men, women, and children - a hard working and generally speaking honest race, who do considerably more for the world than the world does for them.

\footnotetext{
${ }^{9}$ See Anderson for a discussion of the critiques Mayhew's July 1857 performances received (2018: 251-2).

${ }^{10}$ See Anderson for a discussion of the coverage by Reynolds's Newspaper of these meetings in May and June of 1851 (2018: 145-50).
} 
Johnstone here seems to be borrowing language not only from London Labour, quoting statistics, for example, but also from the Reynolds's Newspaper article. Arthur's assertion that costers are "a hard working and generally speaking honest race" is also verbatim what Mr. Palmer asserts about costers, and Arthur's comment that costers "do considerably more than the world does for them" echoes Mr. Taylor's suggestion that Mayhew "had tried to injure a class of society that has never injured him."

Whether or not Johnstone read this article in Reynolds's Newspaper is not verifiable. However, as Mary Shannon's study of the imagined network of Wellington Street has shown, "writers connected to Wellington Street had a large influence on London drama in the 1840s and '50s, as it was not just Dickens who had his famous works adapted for the stage. Reynolds, Jerrold, and Mayhew all had their most well-known London writings turned into popular plays" (2015: 140). These writers worked in close proximity to each other, and together they influenced the stage and were influenced by it. Here Shannon is referencing Reynold's "penny blood" The Mysteries of London (serialised in weekly instalments in 1844-5), but she goes on to discuss how H. Chance Newton and Colin Hazelwood, "another hack dramatist" for the Britannia, "raided publications such as the London Journal and Reynolds's Miscellany for suitable material" (2015: 141). She quotes Newton describing how they "would run through theses periodicals, jotting down the main incidents in the stories thereof, and scissoring out here and there sundry axioms, aphorisms, and moral sentiments, and so forth" and how Hazlewood or his assistants "would pop these moral, patriotic, and other reflections into the play-script then under way" (qtd. in Shannon 2015: 141). That Johnstone would borrow from periodicals such as Reynolds's Newspaper, then, seems plausible and further speaks to the mutual influence of fiction, journalism, and drama.

One of the most telling aspects of the representation of costers in Johnstone's How We Live is Joe's treatment of his donkey. Tony Williams has discussed the ways in which Johnstone's play echoes London Labour in this sense:

The coster's donkey, as Mayhew explains, is an essential part of their lifestyle and trading, and 'many a costermonger will resent the ill-treatment of a donkey, as he would a personal indignity.' [Johnstone's] Joe asserts that donkeys are only dull when ill-used, and threatens to 'whop' anyone he catches 'whooping' his donkey. Mayhew quotes one of his informants saying 'It's nonsense to call donkeys stupid; them's stupid that calls them so.'

(2000: 147)

While I readily agree that there are parallels in the two texts, I would add that Johnstone goes further in characterising the relationship between costers and their donkeys in a positive way. After defending donkeys, as cited above, Joe says, "I know I'd share my last crust with mine, wouldn't I, Neddy", before breaking into song:

My Gal so fair
My moke so rare
With these, what coster can be richer
With that chap there (to Donkey)
I feel no care
My own sweet Gal, my moke and pitcher

(I. i.)

In this song, Joe places his "moke" or donkey, Neddy, on par with his sweetheart, and it is with his donkey that he feels no care. In the play, Joe says that he "learnt that at the penny gaff." Whether Johnstone borrowed from a popular song or it is of his own creation, the lyrics nevertheless characterised the coster as decent and caring toward animals. 
It is interesting that Johnstone chose this song over the one Mayhew cites as "the most popular of all songs with the class [of costers]" in London Labour, "Duck-Legged Dick," the song that was, according to Mayhew, insisted upon by the gallery at "the Vic" $(1851: 15,20)$. This song circulated as a broadside ballad, sometimes titled "Duck Leg'd Dick" and other times titled "Bad Luck Can't Be Prevented." The song tells the lamentable tale of an intemperate coster who ends up in jail and his donkey is taken to "the green-yard" where it starves. Mayhew quotes only the first verse and the chorus; subsequent verses describe how the death of Dick's donkey "fill'd him with dismay" but that he goes on to "cut up the donkey like weal" and distribute its parts, except for the offal which "away he throw'd," around town for profit. With the proceeds, he buys a new donkey that "was warranted sound" but is actually lame and blind. Dick's treatment of his new donkey is narrated in the song's last two verses:

Now the Moke wouldn't go not by coaxing,

So the hampers he took from his back

Then spit in his hands and wopp'd him;

For all the world just like a sack

And not one blow Dick misses

And the people cries, oh! vot a shame!

But he only told 'em to kiss his -

Vot I don't choose for to name.

Some kids from one Dickey Martin,

Took him up for this cruel crime,

Afore the Beak, sure and sartin

And the donkey vos sold for the fine.

Now Dick his spirits couldn't govern, In the office he kick'd up a row,

So vonce more he was sent to the oven

And there the poor devil is now.

(“Duck-Leg'd Dick Had a Donkey.” 18--.)

That Dick is punished for his poor treatment of his donkey is in keeping with both Mayhew's and Johnstone's assessments. The song does not characterise costers as a whole but rather singles out one non-exemplary coster who is a "lush" who "lov'd to swill." When he hits his donkey, "the people cries, oh! vot a shame" and he is taken up for his "cruel crime." The song's chorus, which begins "Yet bad luck can't be perwented," is ironic; it is not bad luck but rather bad behaviour that leads Dick into trouble. The song serves as a warning against both the abuse of alcohol and the abuse of animals. Despite its message, however, "Duck-Legged Dick" contrasts with the depiction of costermonger kindness in Johnstone's song. The straightforwardness of the latter's message constructs the coster as decidedly kind and caring toward his donkey.

Mayhew characterises his London Costermonger in a more negative light in Curious Conversazione. At the end of the scene Mayhew has his costermonger rail against his donkey: "Kem-erp, yer warmint [to the donkey], or I'll varm ye! D'ye think I stole yer! Vy, ye knows I bought yer last night, and paid for yer yesterday morning" (1857: 11). Here the coster calls his donkey a "warmint" (varmint) and threatens to "varm" (warm) him. The souvenir script does not depict the coster actually flogging his donkey, and Mayhew may have chosen these words for an additional opportunity to display his stage Cockney via $/ \mathrm{v} /-/ \mathrm{w} /$ inversion, but the cruelty of the coster's language remains and stands in contrast to the way the coster speaks of his donkey earlier in the scene: "Oh, he's a regular beauty he is! As seveet-tempered too as a Scriptur'-reader [...] Ve never falls out! Ever since I've had him, there a'n't never been no difference bechuxt us" (6). Of course, learning at the end of the scene 
that the reason the coster and his donkey have never fallen out is that they have only been working together for a day adds humour, and this may have been Mayhew's intention. In any case, this depiction of the coster as cruel seems to borrow more from the popular song "Duck-Legged Dick" than it does from Mayhew's interviews with his informants in London Labour. In these performances, Mayhew draws on stage conventions to perform a cross-class "personation" of his informants from London Labour, who were, however constructed and mediated by Mayhew's textual representation of them, real people. Mayhew's appropriation and (mis)representation of the street-sellers did not go unnoticed. During a 27 January 1857 meeting of the Ticket-of-Leave men, part of a series of meetings that Mayhew organised to help improve their situation, one of the parolees railed against Mayhew and what he perceived were his mercenary motives:

I came here to do something in truth and not in fiction, and I wish to caution you against making yourselves so public in speaking your lives in public to benefit another man. That man is Henry Mayhew. His object in calling us together is to sell his books. A nice man is Henry Mayhew a'int he? - to come here and get you to tell your confession?

("Meeting of Ticket-of-Leave Men" 1857: 3)

Who is Mayhew, the speaker asks, to compel our confessions? And what will confessing get us? Our stories will make money for Mayhew but will they have any material consequences on our lives? And, if so, what might those consequences be? The Ticket-of-Leave man's choice of words is telling. In proclaiming, "I came here to do something in truth and not in fiction," he seems to indict Mayhew not only for exploiting London's poor and labouring classes for profit but also for fabricating his representations of them. This meeting occurred a few months before Mayhew took to the stage with Curious Conversazione, but a review in the Daily Telegraph imagines "the virtuous indignation" of the "sturdy, thick-set convictcostermonger, who suddenly rose and gave vent to the exclamation, 'Nice man,'Enery Mayhew, ain't he?" during a meeting of ticket-of-leave men ("A Curious Conversazione" 1857: 3). The reviewer focuses on Mayhew's betrayal of "his old and trusting acquaintances" by "exposing their shams, their dodges, their secrets" and does not suggest that Mayhew is dealing in fiction, but one might imagine the costermonger's indignation at seeing himself portrayed by Mayhew in such a way.

The last point I would like to make about the song "Duck-Legged Dick" is that Dick's experience before "the Beak" (magistrate) is quite different from Joe's in How We Live. In the latter, Joe expresses his gratitude to Arthur for "when before the Beak for pitching into the crusher, you defended and saved me from the Jug" (I. i.). Joe does not explain why he "pitched into," which could mean to either verbally or physically assail, a policeman. But he does later recount an incident to Captain George when "a peeler" asked him to "to move on" and was taken "to the station for a public obstruction" (I. ii.). Audiences would have been aware of the animosity between costers and the police, largely due to the costers' frequent harassment by the police. Mayhew writes of "a New Police regulation" that forbade "stands" or "pitches" and that "each coster, on a market night, is now obliged, under pain of the lock-up house, to carry his tray, or keep moving with his barrow. [...] Even if the pole under the tray or 'shallow' is seen resting on the ground, the policeman on duty is obliged to interfere" (1851: 10). That Arthur would defend Joe and to do it "free gratis," as well as giving Joe "a trifle for a fresh stock," suggests that Joe had been harassed by a policeman, perhaps under this new regulation, and that he was not the instigator of the incident. Johnstone's remark that he 
himself might have been given over to the police and taken before a magistrate for hawking his theatrical wares in the West End comes to mind ("The Oldest Actor on Stage" 1883: 8). By drawing this comparison, I do not mean to conflate Johnstone's experience with that of costermongers and their harassment by police. However, Johnstone did find himself in court defending himself against claims of piracy and nearly faced prison as a result.

The case involved a play that Johnstone co-wrote with Benjamin Barnett and the interpretation of the International Copyright Act of 1852, which was meant to give French authors who registered their works in Britain rights over translation of those works. However, as Charles Reade explains in the preface to his play Poverty and Pride (1856), the act

is so worded as to give a full protection to books, and a limited protection to dramatic pieces. 'Fair imitations and adaptations of a foreign drama are excepted.' The treaty, then, protects the foreign dramatist only against unfair adaptations and imitations.

(reprinted in The Eighth Commandment 1860: 91).

Complying with the act, Reade agreed to pay the authors of the French play from which Poverty and Pride was adapted, Edouard Brisebarre and Eugène Nus, the authors of Les Pauvres of Paris, half of the English profits. ${ }^{11}$ On 12 February 1857, Reade encountered a poster on the door of the Strand Theatre advertising Johnstone and Barnett's "“The Pride of Poverty,' or, 'The Real Poor of London;' a drama, taken from 'Les Pauvres de Paris"' (1860: 98). According to Reade, this was "a piratical version" and "an unauthorized adaptation, so published or played, in matter, form, or title, as to supersede and undersell the authorized version" (100). Reade threatened to sue the manager of the Strand, Thomas Payne, in the Era, but subsequently found himself being sued by Barnett and Johnstone for injury to their reputations. In court, Johnstone testified that

He never read the French piece himself, as he did not sufficiently understand French. He prepared the English piece [from a literal translation provided by Barnett]. He did not do it entirely from the French piece, but from an idea of his own to a great extent.

Barnett testified that the "plot of the French piece was altered altogether, and new characters and scenes created, so as to make the English piece almost an original piece" (135). Nevertheless, it was ruled that Barnett and Johnstone were not able to make their case and they were ordered to pay Reade's costs, a total of $£ 270$. According to Reade, "our attorney threw Mr. Barnett into prison" but he was discharged upon agreeing to pay Reade in $£ 60$ instalments (158-9). As for Johnstone, Reade writes, "Mr. Johnstone is a poor actor. I was told that if I imprisoned him I should merely punish him for his attack on me, and should not extract a shilling from him for my allies" (159).

Johnstone also had his work pirated. In the 10 November 1856 edition of the Liverpool Weekly Mercury, Hugh Shimmin, who like Mayhew was a serialised journalist and social reformer, describes a play he attended, "attracted by the announcement of 'Immense success of the new drama,' 'Crowded houses,' etc., etc." (1856: 3). As Shimmin explains, the "drama professed to give a sketch of how we live in this great town. Singularly enough, it was said to be founded on Mayhew's 'Great World of London"” (3). Like Johnstone's How We Live in the World of London, this play features a character who is unfamiliar with the city and

\footnotetext{
${ }^{11}$ For a discussion of Reade's involvement in the creation of case law regarding adaptation from the French, see Meer (2015).
} 
knowing guides who introduce him to it. But unlike in Johnstone's play, "An American was introduced to see how we live in Liverpool, and for this purpose he was accompanied by an Englishman, an Irishman, and a Welshman" (3). And instead of rescuing the heroine and innocent child, the trio attempt to drug and rob the Yankee. Their plans are thwarted, however, and they end up in Bridewell. This local production borrows from Mayhew and Johnstone (and Moncrieff by way of Johnstone) but brings its own comic types. Maunder cites a review in the Era of Henry Leslie's and Nicholas Rowe's The Orange Girl (24 October 1864, Surrey Theatre) that comments on the "literary harness" that playwrights were required to put on due to two exigencies: the company and the audience (2011: 4). "In observing the first condition," the reviewer explains, "the unfortunate dramatist generally complicates his plot by the introduction of unnecessary characters and in ministering to the second requirement he is apt to become extremely conventional, if not common place, in his language" ("The Theatres, Etc." 1864: 10). It is likely that the Liverpool company had actors who regularly played these comic types, and from Shimmin's account, audiences enjoyed their performance; he writes of "several rounds of applause" (1856: 3).

In terms of the second requirement, regarding the playwright's language, Shimmin's comments would suggest that actors, too, cater to the desires of the audience:

The by-play is not written. The innuendoes are in every instance the production of the dramatic luminary at the time. He it is who panders to - nay, in many instances excites - the depraved tastes of the audience. If what he considers a witty saying does not bring down the applause he so dearly covets, he fancies an obscene jest will, and tries it accordingly. If this fail, he resorts to grimace and action; and when he sees how well his wicked leers take, he goes to still greater lengths, and revels in the devilment his depraved and abandoned conduct creates. These we have noticed in more than one instance, and in other than minor theatres.

(1856: 3)

This account of actors improvising on stage in response to audiences' reactions reminds us that theatre is a collaborative art. Scripts can and often were amended during rehearsals or between performances, and as we have established, actors improvise. The Liverpool production Shimmin describes further complicates questions of authorship and originality. It is also important to note, as Thomas Prasch points out, that both Henry and his brother Augustus borrowed material from The Morning Chronicle and London Labour for other works. Henry reprinted material from The Morning Chronicle in London Labour and reused material from London Labour in his novel 1851; or, the Adventures of Mr. and Mrs. Sandboys, which was serialised in eight parts from February-September, 1851. Augustus used material he collected for London Labour in his novel Paved with Gold; or, the Romance and Reality of the London Streets, which was published in monthly numbers in 1857 (2013: 237). The brothers Mayhew effectively plagiarised themselves and each other even before Johnstone's How We Live and Paved with Gold hit the boards.

\section{Conclusion}

I would like to return briefly to the subject of the "literary harness" and discuss the potential positives that could come from knowing and writing for one's acting company and audience in the minor theatres. During Johnstone's eightieth birthday celebration, J.L. Toole commented on Johnstone's treatment of "low comedians," who most often played the workingclass comic man: 
It has been my good fortune to play in a number of your pieces, and several who are now present have done the same. You have always been most generous to low comedians; as one of them, I can bear testimony to the good they did me professionally, and I don't mind stating to you in confidence that I would rather play Joe, the Orphan, or Jack in Jack and Jack's Brother, than many of the so-called legitimate parts (I hope Irving doesn't hear me). Indeed, your pieces, in many instances, have made us low comedians most prominent, and for this we are grateful.

("The Oldest Actor on the Stage" 1883: 8)

Here Toole emphasises the prominence that Johnstone gave his comic characters. They were not relegated to a comic sub-plot or to the role of comic sidekick of the hero but rather they are central to the plot and central figures themselves. The play that Toole references here is one of Johnstone's earliest: The Gipsy Farmer: or, Jack and Jack's Brother, first performed at the Surrey on 28 April 1845. Toole played Joe in an 1854 revival of the play at the Queen's Theatre Dublin and in an 1858 revival at the Queen's Theatre Edinburgh. The play is a nautical melodrama featuring two sailors, Jack and his brother, Alfred. The gipsy farmer of the title is actually a smuggler, Abel Allnutt, who is impersonating a respectable farmer and who has designs on the mayor's daughter, Margaret, Alfred's sweetheart. The character of Joe is an orphan "found in a haystack," a fact that the audience is reminded of over a dozen times, the refrain becoming a running joke. Joe, however, is not only the melodrama's stock innocent orphan; he is also the comic man. Furthermore, he emerges as the play's main attraction. Several advertisements and reviews highlight the character of Joe or the actor's performance of the character. A review of the 1854 production, for example, makes mention of Toole's performance only: "Mr. J.L. Toole as Joe (a deplorable orphan) was immense" ("Theatricals in Dublin: Queen's Royal Theatre" 1854: 11). Additionally, several productions change the play's title to highlight the character of Joe. An 1856 production at the Britannia was titled Jack and Jack's Brother; or, The Orphan Born in a Haystack!, while an 1867 production at the same theatre flipped the title around to foreground Joe: The Orphan Born in a Haystack!; or, Jack and Jack's Brother. Similarly, an 1846 production at the Marylebone was called Joe the Orphan; or, Jack and Jack's Brother and an 1872 production at Sadler's Wells was called The Gipsy Farmer; or, Joe the Orphan. It is no wonder that Toole would prefer to play Joe than a "so-called legitimate" part.

Johnstone's How We Live did not get renamed to foreground the character of Joe Bunt, but numerous reviews and advertisements reference the performance of actor who played the character, Henry Widdicomb (1813-1868). Widdicomb was engaged as the Surrey's "principal low comedian" by Shepherd when he took over management of the theatre in December 1848 (“Mr. Henry Widdicomb" 1860: 177). The Lloyd's Weekly Newspaper review that opens this essay, for example, remarks: "The real humour of Mr. Widdicomb, who performs a costermonger who comes into a fortune, and does not forget his former friends, is an absolutely perfect personation; and the great delight of the upper audience testify to the merits of the artist in a character which they can best judge" (1856: 8). Similarly, a review in the Era commends the rendering of the character:

Joe Bunt, played with a keen relish of all that is good in human nature by Mr. H. Widdicomb, and so richly crammed with points of unctuous humour that, with that wonderful face of his changing its facetious aspects every minute with a facility that would amaze an anatomist and puzzle a photographer, the roars of laughter that accompany his presence are something to listen to.

(“The Theatres, Etc.” 1856: 10). 
In July of 1856, a few months after How We Live premiered, Shepherd and Creswick attempted to draw crowds to the Surrey with an opera performed in Italian instead of English, a disaster that led to the season being abandoned (Davis and Emeljanow 2001: 31). As William G. Knight points out, "Clearly the opera-goers north of the Thames were not being attracted in sufficient numbers and the Surrey-siders did not take to opera in a foreign language" (1997: 264). When the dramatic season reopened in September, the management relied on their principal low comedian to bring back audiences. An advertisement in the Era touts "the hilarity evoked by Mr. H. Widdicomb" in T.W. Robertson's The Half-Caste and makes a promise for the two pieces that follow, "in both of which Mr. H. Widdicomb will appear" ("Royal Surrey Theatre" 1856a: 1). Even more telling, perhaps, is that in the Surrey version of the French play, "the main incidents are closely followed, though of course a comic personage is introduced for the sake of the ever-welcome Widdicomb" ("Surrey Theatre" 1856: 10). Later in September, the Surrey revived Johnstone's How We Live in the World of London, with Widdicomb reprising his role as Joe Bunt. Not surprisingly, advertisements tout Widdicomb in his "original character" ("Royal Surrey Theatre" 1856b: 1). How We Live played alongside The Half-Caste on Tuesdays, Wednesdays, and Fridays, and closed out the bill each night ("Royal Surrey Theatre" 1856c: 8). That How We Live was revived and played every night when the Surrey was attempting to come back from the previous season's disaster is telling. When Johnstone spoke at this eightieth birthday celebration, he remarked that "Mr. Toole has drawn a humorous comparison between me and Shakespeare. It's a great compliment to be in such company, but I am perfectly satisfied that I am quite unworthy of it" "The Oldest Actor on the Stage" 1883: 8). When we remember that Shakespeare was himself an adaptor, Toole's comparison does not seem like such a stretch.

\section{Bibliography}

Anderson, Christopher. 2018. London Vagabond: The Life of Henry Mayhew. Christopher Anderson.

Booth, Michael. 1965. English Melodrama. London: Hebert Jenkins.

Cohen, Monica F. 2017. Pirating Fictions: Ownership and Creativity in Nineteenth-Century Popular Culture. Charlottesville, VA: University of Virginia Press.

“A Curious Conversazione." 1857. Daily Telegraph quoted in the Shoreditch Observer (1 August): 3.

Davis, Jim and Victor Emeljanow. 2001. Reflecting the Audience: London Theatregoing, 1840-1880. Iowa City, IA: University of Iowa Press.

"Duck-Leg'd Dick Had a Donkey." 18--. James Walker, Printer, Durham. Bodleian John Johnson Collection, Edition - Bod19499, Broadside Ballads Online. http://ballads.bodleian.ox.ac.uk/view/ edition/19499 (accessed 17 November 2021).

“Henry Mayhew's New Periodical on London and Londoners." 1856. The Standard (12 February): 1.

Herdman, Jenna M. 2021. "Curious Conversations: Henry Mayhew and the Street-Sellers in the Media Ecology of London Labour and the London Poor." Journal of Victorian Culture, 26.3 (July): 384-403. DOI: https://doi.org/10.1093/jvcult/vcab002

Holder, Heidi. 2002. "Other Londoners: Race and Class in Plays of Nineteenth-Century London Life." In Imagined Londons, edited by Pamela K. Gilbert, 31-44. Albany: SUNY University Press. 
Humpherys, Anne. 1984. Henry Mayhew. Boston, MA: G. K. Hall \& Company.

Johnstone, John Beer. 1856. How We Live in the World of London; Or, London Labour and the London Poor. Lord Chamberlain's Collection, BL Add. Ms 52958CC. Received 16 March.

Knight, William G. 1997. A Major London 'Minor': The Surrey Theatre 1805-1865. London: The Society for Theatre Research.

“London Labour and London Poor" 1851. Reynolds's Newspaper (18 May): 14.

Maunder, Andrew. 2011. "Mary Barton Goes to London: Elizabeth Gaskell, Stage Adaptation and Working Class Audiences." The Gaskell Journal, 25: 1-18.

Mayhew, Henry. 1851. London Labour and the London Poor. Vol. 1. London: George Woodfall and Son.

Mayhew, Henry. 1856. The Great World of London, Part I. London: David Bogue.

Mayhew, Henry. 1857. A Few Odd Characters Out of the London Streets as Represented by Mr. Henry Mayhew's Curious Conversazione. London: R.S. Francis.

McWilliam, Rohan. 2018. "Melodrama and Class." In The Cambridge Companion to English Melodrama, edited by Carolyn Williams, 163-75. Cambridge: Cambridge University Press. DOI: https://doi.org/10.1017/9781316155875.012

Meer, Sarah. 2015. "Adaptation, Originality and Law: Dion Boucicault and Charles Reade." Nineteenth-Century Theatre and Film, 42.1: 22-38. DOI: https://doi.org/10.1177/ 1748372715617339

“Meeting of Ticket-of-Leave Men.” 1857. Daily News (28 January): 3.

Moncrieff, W. T. 1828; 1888. Tom and Jerry; or, Life in London. London: Richardson.

"Mr. Henry Mayhew's Curious Conversazione." 1857: The Standard (30 July): 6.

"Mr. Henry Widdicomb." 1860. The Players. 2 June: 177-8.

Norwood, Janice. 2015. "Adaptation and the Stage in the Nineteenth Century." Nineteenth-Century Theatre and Film, 42.1: 3-8. DOI: https://doi.org/10.1177/1748372715618635

“An Old London Actor." 1891. The Pall Mall Gazette (8 May): 6.

"The Oldest Actor on the Stage." 1883. The Era (17 March): 8.

Prasch, Thomas. 2013. "Ethnicity as Marker in Henry Mayhew's London Labour and the London Poor." In Fear, Loathing, and Victorian Xenophobia, edited by Marlene Tromp, Maria K. Bachman, and Heidi Kaufman. Columbus, OH: The Ohio State University Press, 231-46.

"Public Amusements: How We Live in London." 1856. Lloyd's Weekly Newspaper (6 April): 8.

Reade, Charles. 1860. The Eight Commandment. London: Trübner and Co.

"Royal Surrey Theatre" 1856a. The Era (14 September): 1.

"Royal Surrey Theatre." 1856b. The Era (21 September): 1.

"Royal Surrey Theatre." 1856c. The Times (29 September): 8.

"Royal Victoria Theatre." 1854. Lloyd's Weekly Newspaper (30 July): 6.

Schroeder, Janice. "The Publishing History of Henry Mayhew's London Labour and the London Poor," BRANCH: Britain, Representation and Nineteenth-Century History, ed. Dino Franco Felluga, Extension of Romanticism and Victorianism on the Net. http://www.branchcollective.org/ ?ps articles $=$ janice-schroeder-the-publishing-history-ofhenry-mayhews-london-labour-and-thelondon-poor (accessed 12 November 2021).

Shannon, Mary. 2015. Dickens, Reynolds, and Mayhew on Wellington Street: The Print Culture of a Victorian Street. New York, NY: Routledge.

[Shimmin, Hugh]. 1856. "Liverpool Life: Its Pleasures, Practices, and Pastimes." Liverpool Weekly Mercury (10 November): 3. 
Stephens, John Russell. 1992. The Profession of the Playwright: British Theatre 1800-1900. Cambridge: Cambridge University Press.

"Surrey Theatre." 1856. The Times (9 September): 10.

Taithe, Bertrand. 1996. The Essential Mayhew: Representing and Communicating the Poor. Concord, MA: Paul and Company.

"The Theatres, Etc.: Surrey." 1856. The Era (13 April): 10.

"The Theatres, Etc.: Surrey." 1864. The Era (30 October): 10.

"Theatrical and Musical Intelligence." 1886. The Morning Post (22 March): 3.

“Theatricals in Dublin: Queen's Royal Theatre.” 1854. The Era (25 June): 11.

Vlock, Deborah. 1998. Dickens, Novel Reading, and the Popular Theatre. Cambridge: Cambridge University Press.

Williams, Tony. 2000. The Representation of London in Regency and Victorian Drama (1821-1881). Lewiston, NY: The Edwin Mellen Press. 